\title{
Audit Deficiency and Auditor Workload: Evidence from PCAOB Triennially Inspected Firms
}

\begin{abstract}
Purpose - This study examines the impact of workloads at public accounting firms on the likelihood of an audit deficiency being identified during a triennial inspection by the Public Company Accounting Oversight Board (PCAOB).

Design/methodology/approach - Using the human resource information disclosed in PCAOB inspection reports, this study constructs two firm-specific workload measures: 1) the ratio of issuer clients to audit partners; and 2) the ratio of issuer clients to professional staff. Firm-level audit deficiency is measured at three levels of severity: 1) Do any of the audit engagements inspected by the PCAOB reveal an audit deficiency?; 2) Are any of the identified audit deficiencies directly related to the auditors' failure to identify a departure from GAAP in the client's financial statement?; and 3) Are any of the identified audit deficiencies associated with a significant adjustment or restatement in the client's subsequent period financial statements? This study uses logistic regression to examine the association between audit deficiency and the workload of public accounting firms.
\end{abstract}

Findings - The empirical evidence suggests that the workload of public accounting firms is positively associated with the likelihood of a deficient audit, auditor's failure to identify client's GAAP departure, and/or an audit deficiency resulting in a significant adjustment or even a restatement of the client's financial statements in the subsequent period.

Originality/value - This study is among the first to investigate the impact of firm workload on deficient audits.

Keywords Audit quality, audit deficiency, Public Company Accounting Oversight Board (PCAOB), auditor workload

Paper Type Research Paper 


\section{Audit Deficiency and Auditor Workload: Evidence from PCAOB Triennially Inspected Audit Firms}

\section{Introduction}

In general, public accounting firms have economic incentives to maximize the leverage of their human resources, and this pressure can result in unrealistic workloads being placed on professional staff and audit partners (International Organization of Securities Commissions (hereafter IOSCO), 2009). Reports of audit failures have led to concerns about the impact of heavy workloads and the lack of proper supervision on audit quality. Hence, this study investigates the association between audit firm workload and the average audit quality at the firm level as manifested in audit deficiencies identified in Public Company Accounting Oversight Board (hereafter PCAOB) inspections. These inspections are the audit industry's independent measure of auditor performance. After an inspection, the PCAOB not only releases the inspection results, it also provides information about the inspected firm, including the number of issuer clients, partners, and professional staff. This information is used to construct two firm-level audit workload measures: 1) the ratio of issuer clients to audit partners; and 2) the ratio of issuer clients to professional staff.

This study's findings indicate that higher workloads in U.S. accounting firms are associated with a higher likelihood of audit deficiency after controlling for the number of issuer clients inspected, number of offices, audit firm's quality control defects, audit fee revenue growth, issuer client portfolio information (such as industry diversification, clients from finance, utility, and hightech industries, or clients with accelerated filing status), and the financial crisis. An analysis of the subsample of accounting firms with audit deficiencies identified in the PCAOB reports shows that firms with higher workloads are likely to have more severe deficiencies such as an auditor's failure to identify a departure from GAAP in the client's financial statement, or a deficiency associated 
with a significant adjustment or even a restatement in the client's subsequent period financial statements. Overall, the results suggest that understaffed accounting firms are more likely to conduct deficient audits.

These empirical findings have important implications for practitioners, standard setters, regulators, and researchers. First, given various stakeholders' desire for publicly available indicators of audit effort (e.g., Bedard et al., 2010; Martin, 2013), the empirical results suggest that workload ratios derived from publicly available PCAOB releases not only meet the information demand from market stakeholders, but also fulfill the PCAOB's mission to develop, disclose, and monitor audit quality and effectiveness.[1] Such publicly available information about audit effort can help to improve the transparency of audit firms, increase market participants' ability to assess audit quality, and ultimately encourage public accounting firms to focus on more adequate staffing of their audit engagements and to avoid excessive leverage of their human resources (Bedard et al., 2010; PCAOB, 2013).

Second, for public accounting firms, the findings suggest that accounting firms should avoid serving too many issuer clients at the expense of sacrificing audit quality. In the current competitive and heavily litigated audit environment, auditors must appropriately balance the costs and benefits of serving multiple issuer clients and must effectively allocate their resources in planning and performing audits so that they manage cost pressure without compromising audit quality. From an audit client's perspective, management and audit committees should take audit firms' workload information into account when making decisions on initial auditor selection, subsequent auditor retention, audit fees, and the evaluation of audit quality.

Third, for standard setters, the findings demonstrate the necessity and importance of the American Institute of Certified Public Accountants (AICPA)'s mandatory requirement that audit 
firms annually evaluate whether they have the necessary human resources to complete their ongoing audit engagements, to ensure that audits meet adequate levels of professional care and competence (AICPA, 2003). In addition, consistent with studies conducted in non-US settings such as China (Gul et al., 2017) and Sweden (Sundgren and Svanstrom, 2014), the findings support the notion that to maintain high quality audits, it is desirable to place an upper limit on the number of audits administered by each partner.

Fourth, for regulators, as the PCAOB uses a risk-based approach in selecting audit engagements for inspection and targets areas where deficiencies are most likely to occur (Swanquist, 2014; Drake et al., 2016;), the workload ratios used in this study can be used to improve the selection of target firms for PCAOB inspections. The PCAOB might consider performing more frequent inspections on public accounting firms where the workload ratio(s) exceed a certain level.

Last but not the least, the results of this study, which used a firm-level workload measure in a U.S. setting, are consistent with those found in studies using partner-level workload measures in non-U.S. settings (e.g., Karjalainen, 2011; Sundgren and Svanstrom, 2014; Gul et al., 2017) where the partner identity is publicly disclosed. Such consistent evidence establishes the construct validity of this study's firm-level workload measure, which captures the average availability and competence of the audit partners and professionals who perform the audits for a firm's issuer clients.

The remainder of this paper is structured as follows. Section 2 provides the institutional background of PCAOB inspections and releases. Section 3 reviews the literature and presents the hypotheses. Section 4 discusses sample selection, variable measurements, and the empirical model. Section 5 describes the empirical results and the conclusions. 


\section{Institutional background}

In 2002, the U.S. Congress enacted the Sarbanes-Oxley Act (SOX) in response to the highprofile financial reporting scandals that had adversely affected investors' confidence in the capital market (e.g., Enron, WorldCom). One of the major outcomes of the SOX Act was the creation of the PCAOB, an independent, not-for-profit body responsible for registering and overseeing the quality of external audits through a rigorous inspection process that examines both audit engagements and public accounting firms' quality control systems to assess compliance with laws, rules, and professional standards for audits of public issuers (PCAOB, 2012).

SOX 102 requires all accounting firms that audit public companies to register with the PCAOB, and SOX 104 charges the PCAOB with the responsibility for conducting inspections of registered accounting firms; specifically, it conducts annual inspections of accounting firms with over 100 issuer clients and triennial inspections of accounting firms with 100 or fewer issuers. The core mandate of the PCAOB is to protect the interests of investors and further the public interest (U.S. Congress, 2002) by monitoring the accounting firms that audit publicly traded companies to ensure the preparation of informative, accurate, and independent audit reports. PCAOB inspectors are afforded privileged insights into the quality of the audits selected for inspection. At the completion of their inspections, the PCAOB issues their findings directly to the inspected accounting firms via inspection reports and then publicizes the reports on the PCAOB website. PCAOB (2012) states that a disclosed deficiency indicates that "the firm did not satisfy its fundamental responsibility to obtain reasonable assurance about whether the financial statements are free from material misstatement." The PCAOB inspection releases include a Part I Report (Inspection Procedures and Certain Observations) and/or a Part II Report (Issues Related to Quality Controls). Part I reports summarize the engagement-level deficiencies identified by the PCAOB 
and are usually released to the public several months after the completed inspection. Part II reports the PCAOB's concerns about potential defects in the audit firm's quality control system, including (a) independence, integrity, and objectivity; (b) personnel management; (c) client acceptance and continuance; (d) engagement performance; and (e) audit process monitoring (PCAOB Quality Control Section 20.07). In addition to the inspection results, the PCAOB release discloses information about the human resources of the accounting firm, such as the number of issuer clients, partners, and professional staff.

\section{Literature review and hypothesis development}

Providing high quality audit services requires diligence and a thorough execution of any audit procedures necessary in a firm's specific circumstances to meet the auditors' professional responsibilities and requirements. The PCAOB (2013, p. A-4) has explicitly expressed concern that, "the greater the workload, the greater the risk audit staff may have insufficient time to perform appropriately the necessary audit procedures and take additional steps that create a quality audit. Staff may become less effective when working long hours, and such an environment may affect the level of due professional care they exercise. For example, a heavy workload may create pressure on the staff to focus more on efficiency in executing auditing procedures than on ensuring the effectiveness of those procedures and of supervision of more junior engagement team members." That is, when facing an understaffed situation, an audit team may perform insufficient audit procedures in an engagement.

In addition, auditing standards require that all audit field work is properly supervised (AU Section 311 Planning and Supervision). "Partners and managers are responsible for oversight of the audit and audit team, which will include less experienced staff. Sufficient time to oversee the work of the audit staff is typically critical to quality" (PCAOB, 2013, p. A-2). The PCAOB (2013) 
also points out that the less time partners spend supervising and reviewing each audit staff member, the greater the risk that partners may not adequately evaluate the audit judgments.[2] Moreover, in-person, on-site review and supervision of audit work is a critical quality control procedure to ensure high quality audit (PCAOB, 2010). When a small number of partners are assigned to a large number of issuer client audits, the workload pressure leads to an increase in the use of electronic reviews from remote locations, rather than in-person, on site reviews and supervision of audit work (AAA Auditing Standard Committee, 2010). Electronic reviews or supervision are convenient, but much less effective than in-person interactions in the reviews (Agoglia et al., 2010) and are thus likely to compromise audit quality and increase the likelihood of a deficient audit.

Moreover, an under-staffed audit team works under great stress given the limited audit resources and the need to complete the audit engagements within a narrow time window. The time pressure increases the likelihood of auditors performing less rigorous audits by engaging in actions that reduce audit quality, such as accepting doubtful audit evidence, truncating a selected sample, readily accepting client personnel explanations as sufficient competent evidential matter, prematurely signing-off on an audit program without performing an audit procedure, or being less responsive to increased risk (Houston 1999; Coram et al., 2004; Lopez and Peters, 2012). Most experimental and archival studies have concluded that time pressure compromises audit quality (Alderman and Deitrick, 1982; Kelley and Margheim, 1990; Houston, 1999; Sweeney and Summers, 2002; Coram et al., 2004; Lopez and Peters, 2012; Lambert et al., 2016).[3] Further, Alderman and Deitrick (1982) point out that inexperienced staff personnel (e.g., first and second year) may not understand the significance a particular step has to the audit as a whole or may not realize or comprehend the possible consequences of a reduction in the audit quality of one of their 
actions. Hence, under time pressure, it is even more critical that partners have sufficient time to review and supervise the audit work performed by inexperienced audit teams.

The above discussion suggests that insufficient human resources in an audit engagement is associated with lower audit quality. It is simply not possible for a small engagement team spreading their audit out over many months to arrive at the same overall effort level as a larger audit team. Appendix A provides an example of an excessive workload resulting in audit deficiencies in all of an accounting firm's audit engagements.[4] The argument presented here is that workload can compromise audit quality through the following channels: time pressure; insufficient audit procedures performed by staff; and insufficient oversight of audit work, such as lack of sufficient in-person, on-site review and supervision. Stated in alternative form, the hypotheses are as follows.

H1a. Ceteris paribus, a higher workload, measured by the number of issuer clients per audit partner, is associated with a higher likelihood of an audit deficiency being identified in a PCAOB inspection.

H1b. Ceteris paribus, a higher workload, measured as the number of issuer clients per professional staff, is associated with a higher likelihood of an audit deficiency being identified in a PCAOB inspection.

\section{Sample selection, variable measurements, and empirical model}

\subsection{Sample and data}

The sample consists of 982 PCAOB inspection releases (2004-2013), 480 of which report audit deficiencies in the inspected audit engagements. They represent 352 out of 512 unique triennially inspected firms' audit deficiencies.[5] All of the inspection releases are obtained from the PCAOB releases available on the PCAOB website, which provides data on audit deficiencies 
and the necessary data to calculate the workload measure.[6] All PCAOB related data used in this study is hand-collected. Audit client related data are downloaded from Audit Analytics database.

This study focuses on triennially inspected audit firms that regularly provide audit reports for 100 or fewer issuers and are subject to PCAOB inspections at least triennially.[7] The companies audited by small audit firms are inherently important to regulators; in 2008 they audited $34 \%$ of U.S. public companies and comprised $97 \%$ of all audit firms (Defond and Lennox, 2011). The PCAOB inspection reports describe the deficiencies discovered during the Board's inspection, and these data are necessary to examine the root cause of audit deficiency in this study's research setting.[8]

\subsection{Measures of audit deficiency}

The data on audit deficiencies are manually collected from PCAOB inspection releases. The PCAOB identifies audit deficiencies as "those deficiencies that, in the inspection team's judgment, resulted in the firm failing to obtain sufficient competent evidence to support its opinion on the financial statements." Examples of Part I deficiencies are failures to perform and document sufficient confirmation of loan and deposit balances, or to perform sufficient audit procedures related to the issuer's allowance for loan losses. Part I engagement-level audit deficiencies are measured using an indicator variable PartI, which is coded 1 if the firm is found to have Part I deficiencies, and 0 otherwise.

Following Gramling et al. (2011), Gunny and Zhang (2013), and Abbott et al., (2012), Part I audit deficiencies are further partitioned into GAAP and GAAS deficiencies. A GAAP deficiency is a deficiency that is directly related to the auditors "failure to identify a departure from GAAP" and/or a particular deficiency that resulted in a restatement of the financial statements. A GAAS deficiency is any audit deficiency that is not a GAAP deficiency, including deficiencies related to 
the performance and documentation of substantive tests. A GAAP deficiency is more serious than a GAAS deficiency because it represents outright audit failure (Francis, 2004) and a breach of the traditional definition of audit quality (DeAngelo, 1981). Gunny and Zhang (2013) show that GAAP deficiency is associated with higher abnormal current accruals and a higher propensity for restatement. A GAAS deficiency is less serious because the implications for financial reporting are not as apparent (Gunny and Zhang, 2013). Thus, PartIGAAP is defined as an indicator variable coded 1 if the firm is found to have a serious GAAP-related Part I deficiency, and 0 otherwise.

This study further investigates the effects of the most serious audit deficiencies by partitioning Part I audit deficiencies according to whether a Part I deficiency results in a subsequent restatement or adjustment. SubqDef is defined as an indicator variable coded 1 if the firm is found to have audit deficiency that results in a restatement or subsequent adjustment of the financial statements, and 0 otherwise.

\subsection{Measures of workload}

Since 2004, PCAOB inspection releases have provided information about each inspected firm's number of issuer clients, partners, and professional staff. Here, this information is used to construct two firm-specific audit workload measures: 1) WorkloadP, the ratio of the number of issuer clients to the number of audit partners; and 2) WorkloadS, the ratio of the number of issuer clients to the number of professional staff. These two workload measures proxy for audit firm size and resources relative to the number of public clients, and reflect the concern that when assigned to an excessive number of public issuers, a partner's and professional staff's ability to adequately supervise and review audit engagements is compromised.[9]

\subsection{Empirical model}

The hypotheses are tested by performing the following logistic regressions: 


$$
\begin{aligned}
\text { Deficiency }_{i t} & =\beta_{0}+\beta_{1} \text { Load }_{i t}+\beta_{2} \text { NumClientInspect }_{i t}+\beta_{3} \text { NumOffc }_{i t}+\beta_{4} \text { PartII }_{i t} \\
& +\beta_{5} \text { Growth }_{i t}+\beta_{6} \text { Experience }_{i t}+\beta_{7} \text { PctNewClt }_{i t}+\beta_{8} \text { Diversity }_{i t} \\
& +\beta_{9} \text { Financial }_{i t}+\beta_{10} \text { Tech }_{i t}+\beta_{11} \text { Utilities }_{i t}+\beta_{12} \text { AcclFlr }_{i t}+\beta_{13} \text { Crisis }_{i t} \\
& +\beta_{14} \text { GCO }_{i t}+\varepsilon_{i t}
\end{aligned}
$$

Deficiency is a placeholder for the three audit deficiency variables defined above: PartI, PartIGAAP, and SubqDef. Load is a placeholder for the two workload ratios defined above: WorkloadP (H1a) and WorkloadS (H1b). As each partner or professional staff member is assigned more issuer clients, their resources and time become stretched, leading to a higher likelihood of audit deficiency. The empirical predictions of $\mathrm{H} 1 \mathrm{a}$ and $\mathrm{H} 1 \mathrm{~b}$ are positive and significant signs for each main variable tested using model (1).

The control variables include the number of issuer clients inspected (NumClientInspect), the number of offices $(\mathrm{NumOffc})$, an indicator variable for a Part II defect in an audit firm's quality control system (PartII), audit fee growth over the last three years (Growth), number of years since PCAOB registration (Experience), percentage of new client (PctNewClt), number of different 2digit SIC industry membership codes in the issuers' clients list (Diversity), and dummy variables for financial industry (Financial), high-tech industry (Tech), utilities industry (Utilities), and accelerated filers (AcclFlr), a dummy variable coded 1 if the year of inspection is 2007 or 2008 (Crisis), and a dummy variable coded 1 if the firm's client portfolio has at least one company receiving going concern opinion $(G C O)$. The prediction is that there is a higher likelihood of audit deficiency if more clients are inspected, if an audit firm grows fast or has a defect in its quality control system, if the client industry membership is more diversified, if auditing clients are new clients, have financial difficulty to continue as a going concern, or in high-tech industries, i.e., positive signs for NumClientInspect, Growth, Diversity, PctNewClt, GCO, and Tech[10]. There is a lower likelihood of audit deficiency when an audit firm faces higher reputation costs or litigation 
risks when the firm has multiple audit offices, gains more experience of PCAOB oversight, audits large accelerated issuers or regulated industry clients, or when audits are performed during the financial crisis, i.e., negative signs for Experience, Financial, Utilities, AcclFlri, and Crisis.

\section{Results}

\subsection{Descriptive statistics and correlations}

The descriptive statistics of all of the variables are reported in Table 1: $48.9 \%$ of the observations have a Part I deficiency, $12.4 \%$ have a GAAP-related Part I deficiency, $6.7 \%$ have a subsequent restatement or adjustment of the client's financial statements, and $7.4 \%$ have Part II defects in the audit quality control system. WorkloadP has a median of 0.750 , and WorkloadS has a median of 0.222 . 
TABLE 1

Descriptive Statistics

\begin{tabular}{|c|c|c|c|c|c|c|c|}
\hline Variables & \# of Obs. & Mean & Min. & $25 \%$ & Median & $75 \%$ & Max. \\
\hline PartI & 982 & 0.489 & 0 & 0 & 0 & 1 & 1 \\
\hline PartIGAAP & 982 & 0.124 & 0 & 0 & 0 & 0 & 1 \\
\hline SubqDef & 982 & 0.067 & 0 & 0 & 0 & 0 & 1 \\
\hline PartII & 982 & 0.074 & 0 & 0 & 0 & 0 & 1 \\
\hline WorkloadP & 982 & 2.776 & 0.033 & 0.333 & 0.750 & 2.250 & 32.000 \\
\hline WorkloadS & 982 & 1.272 & 0.009 & 0.078 & 0.222 & 0.816 & 18.500 \\
\hline NumClientInspect & 982 & 2.944 & 1 & 1 & 2 & 4 & 11 \\
\hline NumOffc & 982 & 2.476 & 1 & 1 & 1 & 3 & 20 \\
\hline Growth & 982 & 0.382 & -0.874 & -0.146 & 0.055 & 0.389 & 10.750 \\
\hline Experience & 982 & 4.311 & 0.482 & 2.145 & 4.121 & 6.008 & 9.030 \\
\hline PctNewClt & 982 & 0.191 & 0 & 0 & 0.100 & 0.333 & 1.000 \\
\hline Diversity & 982 & 5.049 & 1 & 1 & 3 & 7 & 26 \\
\hline Financial & 982 & 0.629 & 0 & 0 & 1 & 1 & 1 \\
\hline Tech & 982 & 0.349 & 0 & 0 & 0 & 1 & 1 \\
\hline Utilities & 982 & 0.108 & 0 & 0 & 0 & 0 & 1 \\
\hline AcclFlr & 982 & 0.371 & 0 & 0 & 0 & 1 & 1 \\
\hline Crisis & 982 & 0.233 & 0 & 0 & 0 & 0 & 1 \\
\hline$G C O$ & 982 & 0.591 & 0 & 0 & 1 & 1 & 1 \\
\hline
\end{tabular}

Notes: *, **, and *** indicate significance at a $10 \%, 5 \%$, and $1 \%$ level, respectively. Table 1 reports the descriptive statistics of all of the variables. PartI is coded 1 if an audit firm is found to have Part I deficiency, and 0 otherwise. PartIGAAP is coded 1 if an audit firm is found to have GAAP related deficiency, and 0 otherwise. SubqDef is coded 1 if an audit firm's client is found to have a subsequent restatement or adjustment, and 0 otherwise. PartII is coded 1 if an audit firm is found to have Part II deficiency, and 0 otherwise. WorkloadP is calculated as number of issuer clients/number of partners. WorkloadS is calculated as number of issuer clients/number of staff members. NumClientInspect is the number of issuer clients inspected. NumOffc is the number of offices. Growth is calculated as (audit fee of current year - audit fee of last year)/audit fee of last year. Experience is the number of days between PCAOB registration and inspection field work start date, divided by 365. PctNewClt is number of new clients / number of total clients. Diversity is the number of distinct 2-digit SIC codes among the clients. Financial is coded 1 if an audit firm has clients in the financial industry (2-digit SIC 60-69), and 0 otherwise. Tech is coded 1 if an audit firm has clients in the high-tech industry (2-digit SIC 35-36), and 0 otherwise. Utilities is coded 1 if an audit firm has clients in the utilities industry (2-digit SIC 49), and 0 otherwise. AcclFlr is coded 1 if an audit firm has clients that are accelerated filers, and 0 otherwise. Crisis is coded 1 if the year is 2007 or 2008, and 0 otherwise. GCO is coded 1 if the firm's client portfolio has at least one company receiving going concern opinion.

Table 2 reports the Pearson correlations among all of the variables. Both WorkloadP and WorkloadS are positively correlated with all of the audit deficiency variables, namely, PartI, PartIGAAP, and SubqDef. This suggests that, in general, accounting firms with higher audit partner and staff workloads tend to have more audit deficiencies. In addition, all three audit deficiency variables are positively associated with defects in the accounting firms' quality control 
system. Moreover, firms that lack experience in PCAOB oversight and have larger, diversified, or risky client portfolio are more likely to have audit deficiencies. 
TABLE 2

\section{Pearson's Correlations}

\begin{tabular}{|c|c|c|c|c|c|c|c|c|c|c|}
\hline & & 1 & 2 & 3 & 4 & 5 & 6 & 7 & 8 & 9 \\
\hline 1 & PartI & 1 & & & & & & & & \\
\hline 2 & PartIGAAP & $0.385 * * *$ & 1 & & & & & & & \\
\hline 3 & SubqDef & $0.275 * * *$ & $0.713 * * *$ & 1 & & & & & & \\
\hline 4 & PartII & $0.204 * * *$ & $0.211 * * *$ & $0.188 * * *$ & 1 & & & & & \\
\hline 5 & WorkloadP & $0.246 * * *$ & $0.238 * * *$ & $0.231 * * *$ & $0.216 * * *$ & 1 & & & & \\
\hline 6 & WorkloadS & $0.214 * * *$ & $0.238 * * *$ & $0.180 * * *$ & $0.218 * * *$ & $0.772 * * *$ & 1 & & & \\
\hline 7 & NumClientInspect & $0.256 * * *$ & $0.175 * * *$ & $0.184 * * *$ & 0.025 & $0.305 * * *$ & $0.173 * * *$ & 1 & & \\
\hline 8 & NumOffc & -0.051 & -0.028 & -0.018 & $-0.092 * * *$ & $-0.154 * * *$ & $-0.148 * * *$ & $0.299 * * *$ & 1 & \\
\hline 9 & Growth & $0.063 * *$ & 0.036 & 0.006 & $0.054 *$ & $0.079 * *$ & $0.115 * * *$ & 0.032 & -0.024 & 1 \\
\hline 10 & Experience & $-0.168 * * *$ & $-0.075 * *$ & $-0.080 * *$ & $-0.166 * * *$ & -0.043 & $-0.079 * *$ & $-0.113 * * *$ & $0.134 * * *$ & $-0.176 * * *$ \\
\hline 11 & PctNewClt & $0.096 * * *$ & $0.107 * * *$ & $0.083 * * *$ & $0.089 * * *$ & $0.232 * * *$ & $0.219 * * *$ & $0.167 * * *$ & 0.018 & $0.394 * * *$ \\
\hline 12 & Diversity & $0.272 * * *$ & $0.187 * * *$ & $0.183 * * *$ & $0.118 * * *$ & $0.630 * * *$ & $0.469 * * *$ & $0.625 * * *$ & $0.104 * * *$ & $0.109 * * *$ \\
\hline 13 & Financial & $0.084 * * *$ & -0.011 & 0.046 & 0.0005 & $0.183 * * *$ & $0.160 * * *$ & $0.291 * * *$ & $0.193 * * *$ & 0.0004 \\
\hline 14 & Tech & $0.142 * * *$ & $0.106 * * *$ & $0.153 * * *$ & $0.094 * * *$ & $0.335 * * *$ & $0.217 * * *$ & $0.320 * * *$ & 0.037 & $0.083 * * *$ \\
\hline 15 & Utilities & $0.133 * * *$ & $0.128 * * *$ & $0.116^{* * *}$ & 0.039 & $0.311 * * *$ & $0.220 * * *$ & $0.307 * * *$ & 0.010 & $0.068 * *$ \\
\hline 16 & AcclFlr & $0.055^{*}$ & 0.011 & $0.055^{*}$ & -0.009 & $0.120 * * *$ & 0.038 & $0.427 * * *$ & $0.252 * * *$ & 0.034 \\
\hline 17 & Crisis & $-0.207 * * *$ & $-0.054^{*}$ & -0.042 & 0.018 & 0.052 & 0.051 & $-0.092 * * *$ & -0.032 & $-0.082 * * *$ \\
\hline \multirow[t]{2}{*}{18} & $G C O$ & $0.213 * * *$ & $0.157 * * *$ & $0.141 * * *$ & $0.157 * * *$ & $0.322 * * *$ & $0.275 * * *$ & $0.333 * * *$ & -0.005 & $0.103 * * *$ \\
\hline & & 10 & 11 & 12 & 13 & 14 & 15 & 16 & 17 & 18 \\
\hline 10 & Experience & 1 & & & & & & & & \\
\hline 11 & PctNewClt & $-0.177 * * *$ & 1 & & & & & & & \\
\hline 12 & Diversity & -0.027 & $0.309 * * *$ & 1 & & & & & & \\
\hline 13 & Financial & $0.063 * *$ & $0.077 * *$ & $0.337 * * *$ & 1 & & & & & \\
\hline 14 & Tech & -0.008 & $0.214 * * *$ & $0.596 * * *$ & $0.089 * * *$ & 1 & & & & \\
\hline 15 & Utilities & -0.001 & $0.086 * * *$ & $0.443 * * *$ & $0.111 * * *$ & $0.227 * * *$ & 1 & & & \\
\hline 16 & AcclFlr & 0.035 & $0.155 * * *$ & $0.385 * * *$ & $0.318 * * *$ & $0.274 * * *$ & $0.134 * * *$ & 1 & & \\
\hline 17 & Crisis & -0.042 & 0.008 & -0.001 & -0.016 & 0.005 & 0.010 & 0.001 & 1 & \\
\hline 18 & $G C O$ & $-0.056^{*}$ & $0.339 * * *$ & $0.521 * * *$ & 0.026 & $0.449 * * *$ & $0.210 * * *$ & $0.146 * * *$ & 0.038 & 1 \\
\hline
\end{tabular}




\subsection{Univariate tests}

The results for the univariate tests of the main variables are reported in Table 3. Overall, the univariate test results are consistent with the predictions in $\mathrm{H} 1 \mathrm{a}$ and $\mathrm{H} 1 \mathrm{~b}$. In particular, out of 982 observations, 480 (502) observations have (do not have) Part I deficiencies. As Panel A of Table 3 shows, the values of WorkloadP for firms with or without Part I deficiencies are 4.111 and 1.931, respectively; the values for WorkloadS for firms with or without Part I deficiencies are 1.931 and 0.643 , respectively. These differences are statistically significant at $1 \%$ with Wilcoxon Z scores of 8.774 for WorkloadP and 9.160 for WorkloadS. This suggests that firms with Part I audit deficiencies have significantly higher workloads.

This study further investigates whether the audit deficiencies in firms with different workloads have different levels of severity. Out of 480 inspections with Part I deficiencies, 122 (358) inspections are identified as having (not having) GAAP-related deficiencies. As shown in Panel B, there are statistically significant differences in the workload levels of both partners and staff in inspections with or without PartIGAAP. Specifically, WorkloadP for firms with or without Part I deficiencies are 6.129 and 3.423, respectively; WorkloadS for firms with or without Part I deficiencies are 3.176 and 1.507, respectively. Both these differences are significant at $1 \%$. Out of 480 inspections with Part I deficiencies, 66 (414) have (do not have) subsequent adjustments or restatements. As shown in Panel C, WorkloadP for firms with or without SubqDef are 7.356 and 3.593, respectively; WorkloadS for firms with or without SubqDef are 3.291 and 1.714, respectively. The Wilcoxon $\mathrm{Z}$ statistics are both significant at $1 \%$. Lastly, similar tests are performed on firms with or without Part II defects in an audit firm's quality control system, and present the results in Panel D of Table 3. Out of 982 observations, 73 (909) observations have (do not have) Part II defects in the firm's quality control system. WorkloadP for firms with or without 
a Part II defect in the audit firm's quality control system are 6.831 and 2.451 , respectively; WorkloadS for firms with or without Part II defects in audit firm's quality control system are 3.594 and 1.086 , respectively. The differences are statistically significant at $1 \%$.

Overall, the univariate analysis suggests that accounting firms with audit deficiencies or defects in their quality control systems usually have high workloads for their audit partners and professional staff. 


\section{TABLE 3 \\ Univariate Tests}

Panel A: PartI Deficiency

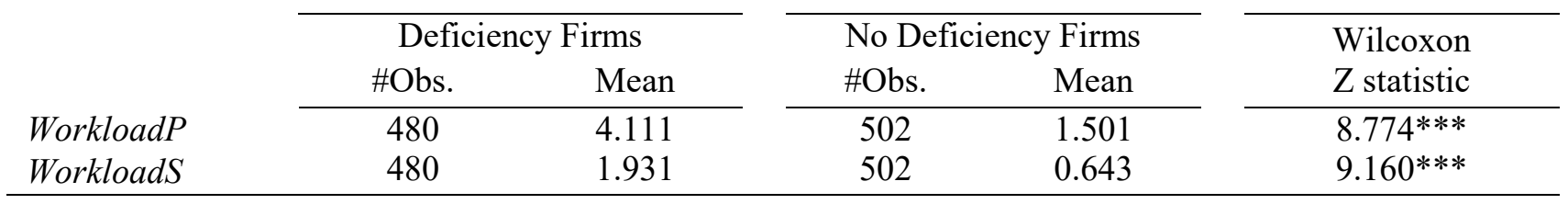

Panel B: PartIGAAP Deficiency

\begin{tabular}{|c|c|c|c|c|c|}
\hline & \multicolumn{2}{|c|}{ Deficiency Firms } & \multicolumn{2}{|c|}{ No Deficiency Firms } & Wilcoxon \\
\hline & \#Obs. & Mean & \#Obs. & Mean & Z statistic \\
\hline WorkloadP & 122 & 6.129 & 358 & 3.423 & $4.560 * * *$ \\
\hline WorkloadS & 122 & 3.176 & 358 & 1.507 & $4.642 * * *$ \\
\hline
\end{tabular}

Panel C: SubqDef Deficiency

\begin{tabular}{|c|c|c|c|c|c|}
\hline & \multicolumn{2}{|c|}{ Deficiency Firms } & \multicolumn{2}{|c|}{ No Deficiency Firms } & \multirow{2}{*}{$\begin{array}{l}\text { Wilcoxon } \\
\text { Z statistic }\end{array}$} \\
\hline & \#Obs. & Mean & \#Obs. & Mean & \\
\hline WorkloadP & 66 & 7.356 & 414 & 3.593 & $4.381 * * *$ \\
\hline WorkloadS & 66 & 3.291 & 414 & 1.714 & $4.276 * * *$ \\
\hline
\end{tabular}

Panel D: PartII Defects

\begin{tabular}{|c|c|c|c|c|c|}
\hline & \multicolumn{2}{|c|}{ Deficiency Firms } & \multicolumn{2}{|c|}{ No Deficiency Firms } & \multirow{2}{*}{$\begin{array}{l}\text { Wilcoxon } \\
\text { Z statistic }\end{array}$} \\
\hline & \#Obs. & Mean & \#Obs. & Mean & \\
\hline WorkloadP & 73 & 6.831 & 909 & 2.451 & $6.789 * * *$ \\
\hline WorkloadS & 73 & 3.594 & 909 & 1.086 & $7.557 * * *$ \\
\hline
\end{tabular}

Notes: *, $* *$, and $* * *$ indicate significance at a $10 \%, 5 \%$, and $1 \%$ level, respectively. T-statistics are in parentheses.

Table 3 reports the univariate tests of the deficiency measures on two work load proxies. PartI is coded 1 if an audit firm is found to have Part I deficiency, and 0 otherwise. PartIGAAP is coded 1 if an audit firm is found to have a GAAP-related deficiency, and 0 otherwise. SubqDef is coded 1 if an audit firm's client is found to have a subsequent restatement or adjustment, and 0 otherwise. PartII is coded 1 if an audit firm is found to have Part II deficiency, and 0 otherwise. WorkloadP is calculated as number of issuer clients/number of partners. WorkloadS is calculated as number of issuer clients/number of staff members. 


\subsection{Logistic regressions}

The logistic regression results presented in columns (1) and (2) of Table 4 suggest that accounting firm workload is positively associated with the probability of a Part I deficiency. Specifically, WorkloadP has a coefficient of 0.068 that is statistically significant at $1 \%$, and WorkloadS has a coefficient of 0.090 that is statistically significant at $5 \%$. The results in Table 4 also suggest that the likelihood of Part I audit deficiency is significantly higher for firms with more clients being inspected, quality control defect, more diversified client portfolio, and more risky client portfolio (i.e., financial difficulty to continue as a going concern). The likelihood is significantly lower for firms facing stronger concern over reputation costs (i.e., the impact of spillover effect of negative reputation on multiple audit offices) and litigation risk (during the financial crisis), or firms with more experience in PCAOB oversight. 
TABLE 4

Part I Deficiency

\begin{tabular}{|c|c|c|}
\hline & $\begin{array}{c}(1) \\
\text { PartI }\end{array}$ & $\begin{array}{c}(2) \\
\text { PartI }\end{array}$ \\
\hline Intercept & $\begin{array}{l}-0.218 \\
(0.927)\end{array}$ & $\begin{array}{l}-0.227 \\
(1.01)\end{array}$ \\
\hline WorkloadP & $\begin{array}{c}0.068 * * * \\
(7.96)\end{array}$ & \\
\hline WorkloadS & & $\begin{array}{c}0.090^{* *} \\
(6.01)\end{array}$ \\
\hline NumClientInspect & $\begin{array}{c}0.181 * * * \\
(12.05)\end{array}$ & $\begin{array}{c}0.188 * * * \\
(13.08)\end{array}$ \\
\hline$N u m O f f c$ & $\begin{array}{c}-0.050^{*} \\
(3.44)\end{array}$ & $\begin{array}{c}-0.058^{* *} \\
(4.72)\end{array}$ \\
\hline PartII & $\begin{array}{c}1.597 * * * \\
(18.57)\end{array}$ & $\begin{array}{c}1.610 * * * \\
(18.88)\end{array}$ \\
\hline Growth & $\begin{array}{c}0.004 \\
(0.004)\end{array}$ & $\begin{array}{c}0.001 \\
(0.0003)\end{array}$ \\
\hline Experience & $\begin{array}{c}-0.120 * * * \\
(13.53)\end{array}$ & $\begin{array}{c}-0.115 * * * \\
(12.66)\end{array}$ \\
\hline PctNewClt & $\begin{array}{r}-0.375 \\
(1.09)\end{array}$ & $\begin{array}{r}-0.353 \\
(0.97)\end{array}$ \\
\hline Diversity & $\begin{array}{l}0.051^{*} \\
(3.20)\end{array}$ & $\begin{array}{c}0.062 * * * \\
(5.13)\end{array}$ \\
\hline Financial & $\begin{array}{l}0.095 \\
(0.33)\end{array}$ & $\begin{array}{l}0.081 \\
(0.24)\end{array}$ \\
\hline Tech & $\begin{array}{r}-0.202 \\
(1.04)\end{array}$ & $\begin{array}{l}-0.177 \\
(0.80)\end{array}$ \\
\hline Utilities & $\begin{array}{l}0.060 \\
(0.05)\end{array}$ & $\begin{array}{l}0.090 \\
(0.11)\end{array}$ \\
\hline AcclFlr & $\begin{array}{c}-0.208 \\
(1.40)\end{array}$ & $\begin{array}{r}-0.202 \\
(1.32)\end{array}$ \\
\hline Crisis & $\begin{array}{c}-1.253 * * * \\
(46.35)\end{array}$ & $\begin{array}{c}-1.238 * * * \\
(45.59)\end{array}$ \\
\hline$G C O$ & $\begin{array}{c}0.370^{* *} \\
(4.12) \\
\end{array}$ & $\begin{array}{c}0.347^{*} \\
(3.64) \\
\end{array}$ \\
\hline $\begin{array}{c}\text { Pseudo } R^{2} \\
\text { Likelihood Ratio } \\
\text { \#Obs. }\end{array}$ & $\begin{array}{c}0.2000 \\
219.16^{* * *} \\
982\end{array}$ & $\begin{array}{c}0.1984 \\
217.13^{* * *} \\
982\end{array}$ \\
\hline
\end{tabular}

Notes: $* * *$, and $* * *$ indicate significance at a $10 \%, 5 \%$, and $1 \%$ level, respectively. Chi-squared values are in parentheses.

Table 4 reports the results of regressing PartI on work load. PartI is coded 1 if an audit firm is found to have Part I deficiency and 0 otherwise. WorkloadP is calculated as number of issuer clients/number of partners. WorkloadS is calculated as number of issuer clients/number of staff members. NumClientInspect is the number of issuer clients inspected. NumOffc is the number of offices. PartII is coded 1 if an audit firm is found to have Part II deficiency and 0 otherwise. Growth is calculated as (audit fee of current year - audit fee of last year)/audit fee of last year. Experience is the number of days between PCAOB registration and inspection field work start date, divided by 365. PctNewClt is number of new clients / number of total clients. Diversity is the number of distinct 2-digit SIC codes among the clients. Financial is coded 1 if an audit firm has clients in the financial industry (2-digit SIC 60-69), and 0 otherwise. Tech is coded 1 if an audit firm has clients in the high-tech industry (2-digit SIC 35-36), and 0 otherwise. Utilities is coded 1 if an audit firm has clients in the utilities industry (2-digit SIC 49), and 0 otherwise. AcclFlr is coded 1 if an audit firm has clients that are accelerated filers, and 0 otherwise. Crisis is coded 1 if the year is 2007 or 2008 , and 0 otherwise. $G C O$ is coded 1 if the firm's client portfolio has at least one company receiving going concern opinion. 
To further examine the impact of workload on audit quality, the association between workload and GAAP-related Part I audit deficiency is examined; the results are reported in Table 5. The logistic regression results presented in columns (1) and (2) of Table 5 suggest that accounting firm workload is positively associated with the probability of a GAAP related part I deficiency. Specifically, WorkloadP has a coefficient of 0.047 that is statistically significant at $5 \%$, and WorkloadS has a coefficient of 0.101 that is statistically significant at $1 \%$. Consistent with Table 4, we find GAAP related audit deficiency is more likely to happen for firms with more clients being inspected by PCAOB, and with quality control defect. Moreover, our empirical evidence suggests that likelihood of GAAP related audit deficiency is lower for firms with audit clients in finance industries. 
TABLE 5

GAAP Related Part I Deficiency

\begin{tabular}{|c|c|c|}
\hline & $\begin{array}{c}(1) \\
\text { PartIGAAP }\end{array}$ & $\begin{array}{c}(2) \\
\text { PartIGAAP }\end{array}$ \\
\hline Intercept & $\begin{array}{c}-1.790 * * * \\
(24.04)\end{array}$ & $\begin{array}{c}-1.852 * * * \\
(25.35)\end{array}$ \\
\hline WorkloadP & $\begin{array}{c}0.047^{* *} \\
(4.70)\end{array}$ & \\
\hline WorkloadS & & $\begin{array}{c}0.101 * * * \\
(9.08)\end{array}$ \\
\hline NumClientInspect & $\begin{array}{c}0.138^{* *} \\
(4.00)\end{array}$ & $\begin{array}{c}0.159 * * \\
(5.23)\end{array}$ \\
\hline NumOffc & $\begin{array}{l}0.020 \\
(0.23)\end{array}$ & $\begin{array}{l}0.018 \\
(0.19)\end{array}$ \\
\hline PartII & $\begin{array}{c}0.821 * * * \\
(7.10)\end{array}$ & $\begin{array}{c}0.795^{* *} \\
(6.59)\end{array}$ \\
\hline Growth & $\begin{array}{r}-0.042 \\
(0.34)\end{array}$ & $\begin{array}{r}-0.056 \\
(0.58)\end{array}$ \\
\hline Experience & $\begin{array}{l}0.029 \\
(0.32)\end{array}$ & $\begin{array}{l}0.040 \\
(0.62)\end{array}$ \\
\hline PctNewClt & $\begin{array}{l}0.736 \\
(1.79)\end{array}$ & $\begin{array}{l}0.709 \\
(1.65)\end{array}$ \\
\hline Diversity & $\begin{array}{r}-0.033 \\
(0.90)\end{array}$ & $\begin{array}{c}-0.032 \\
(0.95)\end{array}$ \\
\hline Financial & $\begin{array}{c}-0.558 * * \\
(4.50)\end{array}$ & $\begin{array}{c}-0.630^{* *} \\
(5.62)\end{array}$ \\
\hline Tech & $\begin{array}{l}0.080 \\
(0.08)\end{array}$ & $\begin{array}{l}0.109 \\
(0.14)\end{array}$ \\
\hline Utilities & $\begin{array}{l}0.405 \\
(1.57)\end{array}$ & $\begin{array}{l}0.431 \\
(1.75)\end{array}$ \\
\hline AcclFlr & $\begin{array}{l}-0.295 \\
(1.10)\end{array}$ & $\begin{array}{l}-0.276 \\
(0.95)\end{array}$ \\
\hline Crisis & $\begin{array}{l}0.097 \\
(0.10)\end{array}$ & $\begin{array}{l}0.115 \\
(0.14)\end{array}$ \\
\hline$G C O$ & $\begin{array}{l}0.207 \\
(0.44)\end{array}$ & $\begin{array}{l}0.161 \\
(0.27)\end{array}$ \\
\hline $\begin{array}{c}\text { Pseudo } R^{2} \\
\text { Likelihood Ratio } \\
\text { \#Obs. }\end{array}$ & $\begin{array}{c}0.0736 \\
36.71 * * * \\
480\end{array}$ & $\begin{array}{c}0.0821 \\
41.14 * * * \\
480\end{array}$ \\
\hline \multicolumn{3}{|c|}{$\begin{array}{l}\text { Notes: } *, * * \text {, and } * * * \text { indicate significance at a } 10 \%, 5 \% \text {, and } 1 \% \text { level, respectively. Chi-squared values are in parentheses. } \\
\text { Table } 5 \text { reports the results of regressing PartIGAAP on work load. PartIGAAP is coded } 1 \text { if an audit firm is found to have GAAP } \\
\text { related deficiency, and } 0 \text { otherwise. WorkloadP is calculated as number of issuer clients/number of partners. WorkloadS is } \\
\text { calculated as number of issuer clients/number of staff members. NumClientInspect is the number of issuer clients inspected. } \\
\text { NumOffc is the number of offices. PartII is coded } 1 \text { if an audit firm is found to have Part II deficiency, and } 0 \text { otherwise. Growth } \\
\text { is calculated as (audit fee of current year - audit fee of last year)/audit fee of last year. Experience is the number of days between } \\
\text { PCAOB registration and inspection field work start date, divided by } 365 \text {. PctNewClt is number of new clients / number of total } \\
\text { clients. Diversity is the number of distinct } 2 \text {-digit SIC codes among the clients. Financial is coded } 1 \text { if an audit firm has clients } \\
\text { in the financial industry (2-digit SIC } 60-69 \text { ), and } 0 \text { otherwise. Tech is coded } 1 \text { if an audit firm has clients in the high-tech industry } \\
\text { (2-digit SIC } 35-36 \text { ), and } 0 \text { otherwise. Utilities is coded } 1 \text { if an audit firm has clients in the utilities industry (2-digit SIC } 49 \text { ), and } \\
0 \text { otherwise. AcclFlr is coded } 1 \text { if an audit firm has clients that are accelerated filers, and } 0 \text { otherwise. Crisis is coded } 1 \text { if the } \\
\text { year is } 2007 \text { or } 2008 \text {, and } 0 \text { otherwise. GCO is coded } 1 \text { if the firm's client portfolio has at least one company receiving going } \\
\text { concern opinion. }\end{array}$} \\
\hline
\end{tabular}


Next, the impact of workload on SubqDef is examined; the results are reported in Table 6. WorkloadP has a coefficient of 0.061 that is statistically significant at $5 \%$, and WorkloadS has a coefficient of 0.065 that is statistically significant at $10 \%$. These results are generally consistent with the prediction that firms with higher workload have more severe audit deficiencies (which lead to subsequent adjustment or restatement). Consistent with Table 4 and 5, we find audit deficiency that is associated with subsequent significant adjustment or restatement is more likely to happen for firms with more clients being inspected by $\mathrm{PCAOB}$, and with quality control defect. Moreover, our empirical evidence suggests that likelihood of such audit deficiency is significantly higher for firms with audit clients in high-tech industry, possibly due to higher audit risk associated with revenue recognition and volatility in the operation in such industry. 
TABLE 6

Subsequent Adjustment or Restatement

\begin{tabular}{|c|c|c|}
\hline & $\begin{array}{c}(1) \\
\text { SubqDef }\end{array}$ & $\begin{array}{c}(2) \\
\text { SubqDef }\end{array}$ \\
\hline Intercept & $\begin{array}{c}-3.082 * * * \\
(36.17)\end{array}$ & $\begin{array}{c}-3.115^{* * *} \\
(36.82)\end{array}$ \\
\hline WorkloadP & $\begin{array}{c}0.061 * * \\
(6.12)\end{array}$ & \\
\hline WorkloadS & & $\begin{array}{c}0.065^{*} \\
(3.00)\end{array}$ \\
\hline NumClientInspect & $\begin{array}{c}0.203 * * \\
(5.84)\end{array}$ & $\begin{array}{c}0.209^{* *} \\
(6.12)\end{array}$ \\
\hline NumOffc & $\begin{array}{c}0.001 \\
(0.001)\end{array}$ & $\begin{array}{r}-0.015 \\
(0.08)\end{array}$ \\
\hline PartII & $\begin{array}{c}0.880^{* *} \\
(5.99)\end{array}$ & $\begin{array}{c}0.913 * * \\
(6.94)\end{array}$ \\
\hline Growth & $\begin{array}{l}-0.112 \\
(1.12)\end{array}$ & $\begin{array}{l}-0.125 \\
(1.34)\end{array}$ \\
\hline Experience & $\begin{array}{l}-0.036 \\
(0.28)\end{array}$ & $\begin{array}{l}-0.022 \\
(0.11)\end{array}$ \\
\hline PctNewClt & $\begin{array}{l}0.479 \\
(0.42)\end{array}$ & $\begin{array}{l}0.559 \\
(0.59)\end{array}$ \\
\hline Diversity & $\begin{array}{c}-0.096^{* *} \\
(5.16)\end{array}$ & $\begin{array}{c}-0.067^{*} \\
(3.00)\end{array}$ \\
\hline Financial & $\begin{array}{l}0.074 \\
(0.04)\end{array}$ & $\begin{array}{c}0.021 \\
(0.003)\end{array}$ \\
\hline Tech & $\begin{array}{c}0.834^{* *} \\
(5.33)\end{array}$ & $\begin{array}{c}0.815^{* *} \\
(5.13)\end{array}$ \\
\hline Utilities & $\begin{array}{l}0.434 \\
(1.22)\end{array}$ & $\begin{array}{l}0.459 \\
(1.39)\end{array}$ \\
\hline AcclFlr & $\begin{array}{l}-0.110 \\
(0.10)\end{array}$ & $\begin{array}{l}-0.126 \\
(0.13)\end{array}$ \\
\hline Crisis & $\begin{array}{c}-0.007 \\
(0.0003)\end{array}$ & $\begin{array}{l}0.045 \\
(0.01)\end{array}$ \\
\hline$G C O$ & $\begin{array}{l}0.361 \\
(0.67) \\
\end{array}$ & $\begin{array}{l}0.310 \\
(0.50)\end{array}$ \\
\hline $\begin{array}{c}\text { Pseudo } R^{2} \\
\text { Likelihood Ratio } \\
\text { \#Obs. }\end{array}$ & $\begin{array}{c}0.0756 \\
37.75 * * * \\
480\end{array}$ & $\begin{array}{c}0.0694 \\
34.50 * * * \\
480\end{array}$ \\
\hline \multicolumn{3}{|c|}{$\begin{array}{l}\text { Notes: *, **, and *** indicate significance at a } 10 \%, 5 \% \text {, and } 1 \% \text { level, respectively. Chi-squared are in parentheses. } \\
\text { Table } 6 \text { reports the results of regressing SubqDef on work load. SubqDef is coded } 1 \text { if an audit firm's client is found to have a } \\
\text { subsequent restatement or adjustment, and } 0 \text { otherwise. WorkloadP is calculated as number of issuer clients/number of partners. } \\
\text { WorkloadS is calculated as number of issuer clients/number of staff members. NumClientInspect is the number of issuer clients } \\
\text { inspected. NumOffc is the number of offices. PartII is coded } 1 \text { if an audit firm is found to have Part II deficiency, and } 0 \\
\text { otherwise. Growth is calculated as (audit fee of current year - audit fee of last year)/audit fee of last year. Experience is the } \\
\text { number of days between PCAOB registration and inspection field work start date, divided by } 365 \text {. PctNewClt is number of new } \\
\text { clients / number of total clients. Diversity is the number of distinct } 2 \text {-digit SIC codes among the clients. Financial is coded } 1 \text { if } \\
\text { an audit firm has clients in the financial industry (2-digit SIC } 60-69 \text { ), and } 0 \text { otherwise. Tech is coded } 1 \text { if an audit firm has } \\
\text { clients in the high-tech industry (2-digit SIC 35-36), and } 0 \text { otherwise. Utilities is coded } 1 \text { if an audit firm has clients in the } \\
\text { utilities industry (2-digit SIC } 49 \text { ), and } 0 \text { otherwise. AcclFlr is coded } 1 \text { if an audit firm has clients that are accelerated filers, and } \\
0 \text { otherwise. Crisis is coded } 1 \text { if the year is } 2007 \text { or 2008, and } 0 \text { otherwise. GCO is coded } 1 \text { if the firm's client portfolio has at } \\
\text { least one company receiving going concern opinion. }\end{array}$} \\
\hline
\end{tabular}


Lastly, in addition to examining audit engagement-level audit deficiencies, this study also examines the impact of workload on the likelihood of defects in an accounting firm's audit quality control, which can potentially impact all issuer clients' engagements. Examples of Part II quality control defects include a lack of technical competence, due care, professional skepticism, or efficient concurring partner review. Many of these quality control defects impact basic audit quality, and they can result in audit deficiencies in the assessment of fraud risks, audit report preparations, audit planning and analytical procedures, and review of journal entries (Hermanson and Houston, 2008). These quality control defects are measured using an indicator variable PartII, coded 1 if the accounting firm is found to have Part II defect, and 0 otherwise. The results in Table 7 suggest that WorkloadP has a coefficient of 0.086 and WorkloadS has a coefficient of 0.108 , both statistically significant at $1 \%$. Moreover, the results in table 7 also suggest that a learning curve exists, the more experience in the PCAOB oversight, the less likely the firm has quality control defect. 
TABLE 7

Part II Quality Control Defect

\begin{tabular}{|c|c|c|}
\hline & $\begin{array}{c}(1) \\
\text { PartII }\end{array}$ & $\begin{array}{c}(2) \\
\text { PartII }\end{array}$ \\
\hline Intercept & $\begin{array}{c}-1.250 * * * \\
(1085)\end{array}$ & $-1.314 * * *$ \\
\hline WorkloadP & $\begin{array}{c}0.086^{* * *} * \\
(11.28)\end{array}$ & \\
\hline WorkloadS & & $\begin{array}{c}0.108 * * * \\
(10.27)\end{array}$ \\
\hline NumClientInspect & $\begin{array}{l}-0.076 \\
(0.75)\end{array}$ & $\begin{array}{r}-0.066 \\
(0.54)\end{array}$ \\
\hline NumOffc & $\begin{array}{l}-0.169 \\
(2.24)\end{array}$ & $\begin{array}{c}-0.195^{*} \\
(2.86)\end{array}$ \\
\hline Growth & $\begin{array}{c}0.003 \\
(0.001)\end{array}$ & $\begin{array}{r}-0.022 \\
(0.08)\end{array}$ \\
\hline Experience & $\begin{array}{c}-0.347 * * * \\
(21.25)\end{array}$ & $\begin{array}{c}-0.330^{* * *} \\
(19.40)\end{array}$ \\
\hline Diversity & $\begin{array}{l}0.004 \\
(0.01)\end{array}$ & $\begin{array}{l}0.036 \\
(0.95)\end{array}$ \\
\hline Financial & $\begin{array}{l}-0.064 \\
(0.05)\end{array}$ & $\begin{array}{l}-0.118 \\
(0.15)\end{array}$ \\
\hline Tech & $\begin{array}{l}0.438 \\
(1.96)\end{array}$ & $\begin{array}{l}0.456 \\
(2.15)\end{array}$ \\
\hline Utilities & $\begin{array}{l}-0.186 \\
(0.19)\end{array}$ & $\begin{array}{l}-0.113 \\
(0.07)\end{array}$ \\
\hline AcclFlr & $\begin{array}{l}-0.076 \\
(0.06)\end{array}$ & $\begin{array}{l}-0.087 \\
(0.08)\end{array}$ \\
\hline Crisis & $\begin{array}{l}0.179 \\
(0.34)\end{array}$ & $\begin{array}{l}0.186 \\
(0.37)\end{array}$ \\
\hline $\begin{array}{c}\text { Pseudo } R^{2} \\
\text { Likelihood Ratio } \\
\text { \#Obs. }\end{array}$ & $\begin{array}{c}0.0682 \\
69.36 * * * \\
982\end{array}$ & $\begin{array}{c}0.0666 \\
67.72 * * * \\
982\end{array}$ \\
\hline \multicolumn{3}{|c|}{$\begin{array}{l}\text { Notes: *,**, and *** indicate significance at a } 10 \%, 5 \% \text {, and } 1 \% \text { level, respectively. Chi-squared values are in parentheses. } \\
\text { Table } 7 \text { reports the results of regressing PartII on work load. PartII is coded } 1 \text { if an audit firm is found to have Part II } \\
\text { deficiency, and } 0 \text { otherwise. WorkloadP is calculated as number of issuer clients/number of partners. WorkloadS is calculated } \\
\text { as number of issuer clients/number of staff members. NumClientInspect is the number of issuer clients inspected. NumOffc is } \\
\text { the number of offices. Growth is calculated as (audit fee of current year - audit fee of last year)/audit fee of last year. } \\
\text { Experience is the number of days between PCAOB registration and inspection field work start date, divided by } 365 \text {. PctNewClt } \\
\text { is number of new clients / number of total clients. Diversity is the number of distinct } 2 \text {-digit SIC codes among the clients. } \\
\text { Diversity is number of distinct } 2 \text {-digit SIC codes among the clients. Financial is coded } 1 \text { if an audit firm has clients in financial } \\
\text { industry (2-digit SIC } 60-69 \text { ), and } 0 \text { otherwise. Tech is coded } 1 \text { if an audit firm has clients in high tech industry (2-digit SIC } \\
35-36 \text { ), and } 0 \text { otherwise. Utilities is coded } 1 \text { if an audit firm has clients in the utilities industry (2-digit SIC 49), and } 0 \text { otherwise. } \\
\text { AcclFlr is coded } 1 \text { if an audit firm has clients that are accelerated filers, and } 0 \text { otherwise. Crisis is coded } 1 \text { if the year is } 2007 \\
\text { or } 2008 \text {, and } 0 \text { otherwise. GCO is coded } 1 \text { if the firm's client portfolio has at least one company receiving going concern } \\
\text { opinion. }\end{array}$} \\
\hline
\end{tabular}




\section{Conclusions}

Using information disclosed in the PCAOB inspection releases, this study investigates the association between firm workloads and the likelihood of audit deficiencies in audit engagements. The empirical evidence suggests that heavy workloads result in less audit effort per audit engagement, resulting in lower audit quality, which is manifested in a higher likelihood of audit deficiencies in the client's audit engagements, ranging from insufficient audit procedures to failures to detect client's departure from GAAP in preparing their financial statements, or even audit failures (i.e., restatements of client's financial statements). Moreover, empirical evidence on the control variables provide two important insights: importance of quality control system of accounting firm and learning curve effects. Specifically, quality control defect significantly increases the likelihood of audit deficiency in the audit engagements of financial statements. The more experience in the PCOAB oversight (standard and inspection), the lower likelihood of the audit deficiency or quality control defect, supporting PCAOB's desired outcome that audit quality is enhanced by PCAOB oversight.

These findings are largely consistent with the notion that high quality audits require knowledgeable, skilled, and experienced auditors who have sufficient time and resources to perform the audit work and to deal with difficult issues as they arise. In addition, high quality audits also require audit engagement partners and more senior staff to be actively involved in risk assessment, planning, supervising, and reviewing the work performed (International Auditing and Assurance Standards Board (IAASB), 2014). The accounting firms should avoid serving too many issuer clients at the expense of sacrificing audit quality. Moreover, client's management and audit committees should take audit firms' workload information into account when making decisions on initial auditor selection, subsequent auditor retention, audit fees, and the evaluation of audit 
quality. Further, our findings demonstrate the necessity and importance of the AICPA's mandatory

requirement that audit firms annually evaluate whether they have the necessary human resources

to complete their ongoing audit engagements, to ensure that audits meet adequate levels of professional care and competence (AICPA, 2003).

\section{References}

Advisory Committee on the Auditing Profession (ACAP). (2008), Final Report, available at: https://www.treasury.gov/about/organizational-structure/offices/.../final-report.pdf (accessed on 15 February 2017).

American Institute of Certified Public Accountants (AICPA). (2003), Acceptance and Continuance of Clients and Engagements. Practice Alert 2003-3. AICPA, New York, NY.

AAA Auditing Standard Committee. (2010), "PCAOB Rulemaking Docket Matter No. 31: PCAOB Release No. 2010-005 Application of the 'Failure To Supervise' Provision of the Sarbanes-Oxley Act of 2002 and Solicitation of Comment on Rulemaking Concepts", available at https://pcaobus.org/Rulemaking/Docket031/009_ASC-AAA.pdf (accessed on 15 February 2017).

Abbott, L.J., Gunny, K.A. and Zhang, T.C. (2012), "When the PCAOB talks, who listens? Evidence from stakeholder reaction to GAAP-deficient PCAOB inspection reports of small auditors", Auditing: A Journal of Practice \& Theory, Vol. 32 No. 2, pp. 1-31.

Agoglia, C.P., Brazel, J.F., Hatfield, R.C. and Jackson, S.B. (2010), "How do audit workpaper reviewers cope with the conflicting pressures of detecting misstatements and balancing client workloads?”, Auditing: A Journal of Practice \& Theory, Vol. 29 No. 2, pp. 27-43.

Alderman, C.W. and Deitrick, J.W. (1982), “Auditors' perceptions of time budget pressures and premature sign-offs: A replication and extension", Auditing: A Journal of Practice \& Theory, Vol. 1 No. 2, pp. 54-68.

Bedard, J.C., Johnstone, K.M. and Smith, E.F. (2010), “Audit quality indicators: A status update on possible public disclosures and insights from audit practice", Current Issues in Auditing, Vol. 4 No. 1, pp. C12-C19.

Buchheit, S. and Buslepp, W.L. (2016), "PCAOB Form 2 disclosure: A firm-level signal of audit quality?", working paper. University of Alabama, 26 January.

Coram, P., Ng, J. and Woodliff, D.R. (2004), "The effect of risk of misstatement on the propensity to commit reduced audit quality acts under time budget pressure", Auditing: A Journal of Practice \& Theory, Vol. 23 No. 2, pp. 159-167.

DeAngelo, L.E. (1981), “Auditor size and audit quality”, Journal of Accounting and Economics, Vol. 3 No. 3, pp. 183-199. 
DeFond, M.L. and Lennox, C.S. (2011), "The effect of SOX on small auditor exits and audit quality", Journal of Accounting and Economics, Vol. 52 No. 1, pp. 21-40.

Drake, K.D., Goldman, N.C. and Lusch, S.J. (2015), "Do income tax-related deficiencies in publicly disclosed PCAOB Part II reports influence audit client financial reporting of income tax accounts?", The Accounting Review, Vol. 91 No. 5, pp. 1411-1439.

Financial Reporting Council (FRC). 2008. Audit Quality Framework, available at: https://frc.org.uk/Our-Work/Publications/FRC-Board/The-Audit-Quality-Framework-(1)File.pdf (accessed on 15 February 2017).

Francis, J.R. (2004), “What do we know about audit quality?”, The British Accounting Review, Vol. 36 No. 4, pp. 345-368.

Goodwin, J. and Wu, D. (2015), "What is the relationship between audit partner busyness and audit quality?", Contemporary Accounting Research, Vol. 33 No. 1, pp. 341-377.

Gramling, A.A., Krishnan, J. and Zhang, Y. (2011), “Are PCAOB-identified audit deficiencies associated with a change in reporting decisions of triennially inspected audit firms?", Auditing: A Journal of Practice \& Theory, Vol. 30 No. 3, pp. 59-79.

Gul, F.A., Ma, M.S. and Lai, K. (2012), “Auditing multiple public clients, partner-client tenure and audit quality", Journal of International Accounting Research, 2017, forthcoming.

Gunny, K.A. and Zhang, T.C. (2013), "PCAOB inspection reports and audit quality", Journal of Accounting and Public Policy, Vol. 32 No. 2, pp. 136-160.

Hermanson, D.R. and Houston, R.W. (2008), 'Quality control defects revealed in smaller firms' PCAOB inspection reports", The CPA Journal, Vol. 78 No. 12, p. 36.

Houston, R.W. (1999), “The effects of fee pressure and client risk on audit seniors' time budget decisions", Auditing: A Journal of Practice \& Theory, Vol. 18 No. 2, pp. 70-86.

International Auditing and Assurance Standards Board (IAASB). (2014), A framework for audit quality key elements that create an environment for audit quality. Available at: https://www.ifac.org/publications-resources/framework-audit-quality-key-elementscreate-environment-audit-quality (accessed on February 15, 2017).

International Organization of Securities Commissions (IOSCO). (2009), Transparency of Firms that Audit Public Companies. Available at: ttp://www.iosco.org/library/pubdocs/pdf/IOSCOPD302.pdf (accessed on February 15, 2017).

Karjalainen, J. (2011), “Audit partner specialization and earnings quality of privately-held companies", working paper, University of Alabama.

Kelley, T. and Margheim, L. (1990), "The impact of time budget pressure, personality, and leadership variables on dysfunctional auditor behavior", Auditing: A Journal of Practice \& Theory, Vol. 9 No. 2, pp. 21-42. 
Lambert, T.A., Jones, K.L., Brazel, J.F. and Showalter, D.S. (2016), “Audit time pressure and earnings quality: An examination of accelerated filings", working paper, Lehigh University.

López, D.M. and Peters, G.F. (2012), "The effect of workload compression on audit quality", Auditing: A Journal of Practice \& Theory, Vol. 31 No. 4, pp. 139-165.

Martin, R.D. (2013), “Audit quality indicators: Audit practice meets audit research”, Current Issues in Auditing, Vol. 7 No. 2, pp. A17-A23.

Public Company Accounting Oversight Board (PCAOB). (2008), Rules on periodic reporting by registered public accounting firms. PCAOB Release No. 2008-004.

Public Company Accounting Oversight Board (PCAOB). (2009), Engagement Quality Review. Auditing Standard No. 7.

Public Company Accounting Oversight Board (PCAOB). (2012), Information for Audit Committees about the PCAOB Inspection Process. PCAOB Release No. 2012-003.

Public Company Accounting Oversight Board (PCAOB). (2013), Standing Advisory Group Meeting: Discussion-Audit Quality Indicators.

Sundgren, S. and Svanström, T. (2014), “Auditor-in-Charge Characteristics and Going-concern Reporting”, Contemporary Accounting Research, Vol. 31 No. 2, pp. 531-550.

Swanquist, Q.T. (2014), “Client Responses to Non-Compliant Audits: An Analysis of Clients Targeted by PCAOB Inspection”, working paper, University of Tennessee.

Sweeney, J.T. and Summers, S.L. (2002), “The effect of the busy season workload on public accountants' job burnout”, Behavioral Research in Accounting, Vol. 14 No. 1, pp. 223245. 


\section{Appendix A: PCAOB Release No. 104-2013-058A[11]}

Headquartered in Los Angeles, California, Kabani \& Company, Inc. was inspected by PCAOB in 2011. Below is the basic information about the company being inspected.

$\begin{array}{ll}\text { Number of officers: } & 1 \text { (Los Angeles, California) } \\ \text { Ownership Structure: } & \text { Professional corporation } \\ \text { Number of Partners } & 1 \\ \text { Number of professional staff } & 31 \\ \text { Number of issuer audit client } & 46\end{array}$

The deficiencies identified in all six of the audits reviewed included deficiencies of such significance that it appeared to the inspection team that the Firm, at the time it issued its audit report, had not obtained sufficient competent evidential matter to support its opinion on the issuer's financial statements. Those deficiencies were

(1) the failure to perform sufficient procedures to test the classification of long-lived assets;

(2) the failure, in two audits, to perform sufficient procedures to test accounts receivable;

(3) the failure to perform sufficient procedures to evaluate transactions with related parties;

(4) the failure to perform sufficient procedures to evaluate investments in joint ventures;

(5) the failure to perform sufficient procedures to test research and development costs;

(6) the failure to perform sufficient procedures to test net capitalized software development costs;

(7) the failure to perform sufficient procedures to test revenue;

(8) the failure to perform sufficient procedures to test intangible assets;

(9) the failure to perform sufficient procedures to test inventory; and

(10) the failure, in four audits, to perform sufficient procedures to test amounts reported in statements of cash flows.

One of the deficiencies described above related to auditing an aspect of an issuer's financial statements that the issuer revised in a restatement prior to the primary inspection procedures. 


\section{Appendix B: Variable Definitions}

\begin{tabular}{|c|c|c|}
\hline Variable & Description & Definition \\
\hline PartI & Part I deficiency & Coded 1 if an audit firm is found to have Part I deficiency, and 0 otherwise. \\
\hline PartIGAAP & $\begin{array}{l}\text { GAAP-related Part I } \\
\text { deficiency }\end{array}$ & $\begin{array}{l}\text { Coded } 1 \text { if an audit firm is found to have GAAP related deficiency, and } 0 \\
\text { otherwise. }\end{array}$ \\
\hline SubqDef & $\begin{array}{l}\text { Subsequent restatement or } \\
\text { adjustment }\end{array}$ & $\begin{array}{l}\text { Coded } 1 \text { if an audit firm's client is found to have subsequent restatement or } \\
\text { adjustment, and } 0 \text { otherwise. }\end{array}$ \\
\hline PartII & Part I deficiency & Coded 1 if an audit firm is found to have Part II deficiency, and 0 otherwise. \\
\hline WorkloadP & Partner's workload & Number of issuer clients/number of partners. \\
\hline WorkloadS & Staff’s workload & Number of issuer clients/number of professional staff. \\
\hline NumClientInspect & Number of clients inspected & Number of issuer clients inspected. \\
\hline NumOffc & Number of offices & Number of offices. \\
\hline Growth & Audit fee growth & (Audit fee of current year - audit fee of last year)/audit fee of last year. \\
\hline Experience & $\begin{array}{l}\text { Number of years since } \\
\text { PCAOB registration }\end{array}$ & $\begin{array}{l}\text { Number of days between PCAOB registration and inspection field work start } \\
\text { date, divided by } 365 \text {. }\end{array}$ \\
\hline PctNewClt & Percentage of new clients & $\begin{array}{l}\text { Number of new clients / number of total clients. Data source: Audit Analytics } \\
\text { Database }\end{array}$ \\
\hline Diversity & Diversity of clients & Number of distinct 2-digit SIC codes in client list. \\
\hline Financial & $\begin{array}{l}\text { Financial industry dummy } \\
\text { variable }\end{array}$ & $\begin{array}{l}\text { Coded } 1 \text { if an audit firm has clients in the financial industry (2-digit SIC 60-69), } \\
\text { and } 0 \text { otherwise. }\end{array}$ \\
\hline Tech & $\begin{array}{l}\text { High-tech industry dummy } \\
\text { variable }\end{array}$ & $\begin{array}{l}\text { Coded } 1 \text { if an audit firm has clients in the high-tech industry (2-digit SIC 35-36), } \\
\text { and } 0 \text { otherwise. }\end{array}$ \\
\hline Utilities & $\begin{array}{l}\text { Utilities industry dummy } \\
\text { variable }\end{array}$ & $\begin{array}{l}\text { Coded } 1 \text { if an audit firm has clients in the utilities industry (2-digit SIC 49), and } \\
0 \text { otherwise. }\end{array}$ \\
\hline AcclFlr & $\begin{array}{l}\text { Accelerated filer dummy } \\
\text { variable }\end{array}$ & Coded 1 if an audit firm has clients that are accelerated filers, and 0 otherwise. \\
\hline Crisis & $\begin{array}{l}\text { Financial crisis dummy } \\
\text { variable }\end{array}$ & Coded 1 if the year is 2007 or 2008 , and 0 otherwise. \\
\hline$G C O$ & Going concern opinion & $\begin{array}{l}\text { Coded } 1 \text { if the firm's client portfolio has at least one company receiving going } \\
\text { concern opinion. Data source: Audit Analytics Database }\end{array}$ \\
\hline
\end{tabular}


1. For information on the PCAOB's oversight function see Advisory Committee on the Auditing Profession (ACAP, 2008) and PCAOB (2008).

2. Similarly, the International Auditing and Assurance Standards Board (IAASB) has highlighted the need for adequate partner and staff time in its Framework for Audit Quality (IAASB 2014). The Financial Reporting Council's Audit Quality Framework also states that one of the key factors affecting audit quality is the skills and personal qualities of engagement team members (Financial Reporting Council 2008). Consistent with these guidelines, Gul, Ma, and Lai (2017) point out that a key driver of audit quality could be the experience and competency of the professionals delivering the audit services. Audit firms can quickly improve their capacity by recruiting new staff, but audit partners cannot increase capacity in this way to cope with more audit clients. Consequently, as the number of public clients increases, an audit partner's resources and time are more likely to be stretched, leading to lower audit quality.

3. For example, experimental research (e.g., Coram, Ng, \& Woodliff, 2004) shows that under stronger time pressure, auditors are likely to concede more and to focus on whether the financial reporting outcome achieves minimal compliance with technically correct GAAP, resulting in lower audit quality. Moreover, in a large sample of public companies, Lambert, Jones, Brazel, and Showalter (2016) find that SEC rules on 10-K acceleration filings (338128 and 33-8644) that impose time pressure on the audits of registered firms have a negative impact on audit quality. Lopez and Peters (2012) provide archival evidence that workload compression during the busy season leads to dysfunctional behavior that lowers audit quality. Recent non-U.S. studies investigate the impact of audit partner busyness on the audit quality in settings where audit partners identification is publicly disclosed, including China (Gul et al., 2014), Finland (Karjalainen, 2011), Australia (Goodwin and Wu, 2015), and Sweden (Sundgren and Svanstrom, 2014).

4. The inspection results cited in Appendix A (PCAOB release No. 104-2013-058A) report on a firm that consists of a single partner and 31 audit staff who audit 46 issuer clients. It is hard to believe that such an understaffed firm could audit so many issuer client successfully. It is unsurprising that audit deficiencies are identified and that "all six of the audits reviewed included deficiencies of such significance that it appeared to the inspection team that the Firm, at the time it issued its audit report, had not obtained sufficient competent evidential matter to support its opinion on the issuer's financial statements." In addition, such singlepartner firms usually have to "outsource" a concurring partner review, which is a quality control defect (Hermanson and Houston, 2008).

5. In 2003, the PCAOB began inspecting registered accounting firms that perform audits of US publicly traded companies. On Aug 26, 2004, the PCAOB released inspection reports of the Big 4 audit firms, which were inspected in 2003. On January 21, 2005, PCAOB released the inspection reports of the first batch of triennial firms (Battelle \& Battelle LLP; Clyde Bailey, P.C.; Dudley, Hopton-Jones, Sims \& Freeman, PLLP; Moore Stephens Frost, PLC) for inspections performed in 2004.

6. See https://pcaobus.org/Inspections/Reports/Pages/default.aspx, accessed on March 2, 2017.

7. Since inception, only the eight largest auditors have been consistently subject to annual inspection, including BDO, Deloitte, Crowe, Ernst and Young, Grant Thornton, KPMG, McGladrery (now called RSM), and PWC. Almost all of the remaining audit firms have been 
subject to triennial inspections, except for Malone Bailey whose first annual inspection was released in 2010 (PCAOB, 2012).

8. Notably, clients' names are not disclosed in these PCAOB reports of audit deficiencies. In other words, the PCAOB inspection reports are auditor-specific rather than client-specific.

9. The measure used in this paper is similar to the workload measure used in a recent working paper by Buchheit and Bushlepp (BB) (2016) but differs in two important points. First, the $\mathrm{BB}$ workload measure is constructed from PCAOB Form 2 releases, starting from the second quarter of 2010, which is mandated by PCAOB release No. 2008-04 (Rules on periodic reporting by registered public accounting firms). The workload measure in this study covers the sample period from 2004 but adopts different data resources, which increase the power of the tests and resolve the limitation of the short sample period in Buchheit and Bushlepp's paper (discussed on page 29). The results of this study show the negative association between workload and audit quality that occurs during more turbulent economic times (pre-2010) and over the longer sampler period. Second, the new measure is based on the data collected by the PCAOB during its inspections, rather than data drawn from the annual self-reporting in Form 2. Such data are not only more reliable, but more importantly, they are a better fit with this study's research question because they provide perfect matching of firm human resource information at the time of the inspection; the measure in BB is based on annual filings, which does not necessarily reflect the exact human resource information during the audit inspection. Therefore, using the human resource information disclosed in the PCAOB inspection rather than the Form 2 filing is a much better research design choice for this study.

10. Revenue recognition in high-tech industries is more risky (Bedard et al., 2010), hence more likely to result in audit deficiency.

11. Available at (http://pcaobus.org/Inspections/Reports/Documents/2013_Kabani_Company_Inc.pdf). (retrieved on February 25, 2017) 